\author{
Jolanta Spętana
}

ORCID 0000-0002-2543-2120

\title{
PROFILAKTYKA EGZYSTENCJALNA WOBEC ZACHOWAŃ SUICYDALNYCH W OKRESIE WCZESNEJ DOROSLOŚCI
}

\begin{abstract}
Slowa kluczowe: profilaktyka egzystencjalna, zachowania suicydalne, młodzi dorośli, edukacja dorosłych, sens życia.

Streszczenie: Zjawisko zachowań suicydalnych młodych dorosłych obserwowane jest od wielu lat nie tylko w Polsce. W tekście przedstawiono wybrane obszary współczesnych zagrożeń kondycji egzystencjalnej, a także zaprezentowano rolę szeroko pojętej profilaktyki, akcentując potrzebę profilaktyki egzystencjalnej wobec zachowań suicydalnych w okresie wczesnej dorosłości.
\end{abstract}

\section{Wprowadzenie - wokół przyczyn kryzysu egzystencjalnego człowieka}

Spośród wielu przeobrażeń towarzyszących współczesnemu człowiekowi, uwikłanych w kontekst kulturowy, gospodarczy, technologiczny, a szerzej cywilizacyjny, obok licznych szans i możliwości rozwoju, na uwagę zwracają składowe funkcjonowania zarówno w wymiarze jednostkowym, jak i zbiorowym, klasyfikowane jako zagrożenie dla kondycji egzystencjalnej. W obliczu pojawiających się nowych trendów i procesów mogących stanowić egzemplifikację czy też wypadkową powyższych przeobrażeń, generowane są nowe kategorie i odsłony istniejących problemów społecznych. W kontekście jednostkowym oznacza to kompilację wielu dychotomicznych opcji działania. $Z$ jednej strony wobec rosnących wymagań kompetencyjnych uruchamiany jest potencjał konstruktywnych rozwiązań, tworzony na bazie wiedzy całożyciowej, doświadczenia, wykształcenia, edukacji permanentnej i autoedukacji, wpisanych w całożyciowy projekt edukacyjny jednostki. $\mathrm{Z}$ drugiej zaś strony przerastające możliwości samodzielnego rozwiązania sytuacje problemowe generują szereg negatywnych opcji działania skutkujących ryzykiem kryzysu egzystencjalnego, który w konsekwencji może przybrać postać działań autodestrukcyjnych, w tym również zachowań suicydalnych.

Próba retrospektywnego, a zarazem holistycznego spojrzenia na sytuację egzystencjalną człowieka w okresie wczesnej dorosłości, a tym samym wskazania potencjalnych przyczyn kryzysu egzystencjalnego, odsyłając do szeregu wielorako uwarunkowanych aspektów, szczególnie eksponuje kategorie trwałości i zmienności. Implementowane w świadomości zbiorowej w ramach modelu 
egzystencji opartego na postmodernistycznych założeniach braku jednoznaczności i fragmentaryczności doświadczeń w płynnej rzeczywistości, docierając do będącego w ciągłym procesie zmian dorosłego - uczącego się, mogą skutkować poczuciem zagubienia i globalnej dezorientacji, a w konsekwencji kryzysem. Do przyczyn kryzysu zaliczyć można prospektywiczną wizję rzeczywistości nie tylko społecznej, ale i indywidualnej, szczególnie gloryfikującej postęp będący swoistym dogmatem, w której wszelka trwałość ma być zastąpiona zmiennością, wraz z zanegowaniem wartości przeszłości. Warto w tym kontekście zauważyć, że wzmacnianie procesu autonomizacji jednostki dokonuje się równocześnie z osłabianiem tradycyjnych hierarchii wartości, a usamodzielniający się w ten sposób świat ludzki, jak dowodzi Bogdan Suchodolski, szuka sam w sobie swych praw i wartości sankcjonowanych z jednej strony w postaci pracy, nauki, techniki czy organizacji, z drugiej zaś w postaci historii umożliwiającej kumulowanie osiągnięć i wychowującej człowieka (1999, s. 36). Niezdolność zaadaptowania się do tak niestałego horyzontu doświadczeń uwidacznia się ostatecznie w postaci kryzysu egzystencjalnego związanego z zachowaniami samobójczymi i znajduje swoją reprezentację $\mathrm{m}$.in. $\mathrm{w}$ obszarze szeroko pojętej kategorii zdrowia oraz na poziomie wzrostu zapotrzebowania na profesjonalną wieloaspektową pomoc specjalistyczną oraz psychoprofilaktykę, ze szczególnym uwzględnieniem wielopoziomowej profilaktyki egzystencjalnej.

Celem artykułu, powstałego na bazie zastosowania metody analizy tekstu, jest próba ukazania zróżnicowanych uwarunkowań towarzyszących zachowaniom suicydalnym w okresie wczesnej dorosłości oraz wskazanie działań zaradczych i profilaktycznych wobec problemu samobójstw.

\section{Wczesna dorosłość - ryzyko kryzysu egzystencjalnego i zachowań suicydalnych}

Nieodmienne tło towarzyszące przechodzeniu z okresu adolescencyjnego w dorosłość stanowią liczne przeobrażenia socjokulturowe, zarazem zmniejszające motywację młodych ludzi do angażowania się w dorosłe role społeczne i prowadzące do ich odraczania w czasie, jak i sprzyjające generowaniu wielu zagrożeń indywidualnych i społecznych. Okresowi wczesnej dorosłości (18-35 lat), ujmowanemu jako rodzaj perspektywicznej inwestycji, budowanej na kapitale tożsamości, której brak wiąże się z podstawowym ryzykiem tej fazy - niepodjęciem lub podjęciem w niewłaściwy sposób podstawowych ról społecznych wyznaczających funkcjonowanie osoby dorosłej (Harwas-Napierała, 2014) może towarzyszyć wielopostaciowy kryzys egzystencjalny obejmujący m.in. zachowania suicydalne. Do składowych opisywanego kryzysu rozumianego jako niemożność samodzielnego rozwiązania sytuacji problemowych skutkująca załamaniem się podstawowych struktur obronnych jednostki na poziomie psychospołecznym zaliczyć należy szereg uwarunkowań obejmujących nowe zjawiska, procesy i trendy społeczne, 
w tym zmiany sposobu wywiązywania się z podstawowych ról społecznych oraz podejmowanie nowych ról wymuszające na młodych dorosłych konieczność adaptacji do nieustannie zmieniającej się sytuacji. Stanowi to szczególne zagrożenie zwłaszcza wobec nasilania się licznych negatywnych zjawisk społecznych takich jak emigracja, bezrobocie, samotne rodzicielstwo, wzrastająca liczba rozwodów, zmiany w epidemiologii zaburzeń psychicznych, starzenie się populacji etc. (Malina, 2014, s. 8). Wyłaniające się z powyższego składowe zaliczane do kategorii zagrożeń kondycji egzystencjalnej, dezintegrujących osobowość i działanie jednostki, można skategoryzować biorąc pod uwagę kryterium etiologii jako: 1) biologiczne, np.: choroba, depresje, nerwice, stany depresyjne, nałogi, a także lęk; 2) społeczne, np.: trudna sytuacja socjobytowa, utrata pracy; 3) sytuacyjne/relacyjne, np. rozpad rodziny, zawód uczuciowy.

Istotnym czynnikiem mającym wpływ na doświadczenie kryzysu jest niezdolność do poznawczego opracowania i zrozumienia coraz bardziej złożonej i dynamicznie zmieniającej się rzeczywistości oraz poczucie zagubienia pomiędzy adolescencją a wczesną dorosłością, co w konsekwencji może przyczyniać się do wzrostu poziomu lęku bądź agresji, doprowadzić do wycofywania się z aktywności i zaburzeń w kształtowaniu się tożsamości (Brzezińska, Piotrowski, 2009, s. 5) mogących w efekcie przybrać postać kryzysu suicydalnego. W odniesieniu do sytuacji młodych dorosłych szczególne znaczenie przypisywane jest lękowi (biologicznemu, społecznemu, moralnemu i dezintegracyjnemu) i wyzwalającym postawę lękową sytuacjom życiowym związanym z: bezpośrednim zagrożeniem życia, zagrożeniem społecznym, niemożnością dokonania właściwego wyboru aktywności, zachwianiem istniejącej struktury interakcji z otaczającym światem (Kępiński, 1989, s. 491).

W kontekście ryzyka kryzysu kondycji egzystencjalnej na szczególną uwagę zasługuje obszerny katalog zagrożeń okresu wczesnej dorosłości obejmujący: brak zaangażowania w role strukturujące dorosłe życie, zajmowanie się dalszym określaniem własnej tożsamości; brak niezależności od innych (finansowej, emocjonalnej); nadmierne wydłużanie wczesnej dorosłości jako fazy przejściowej w oczekiwaniu na stabilizację; nadmiernie silne związki z rodzicami i niemożliwość ich osłabienia oraz przeniesienia uczuć na inną osobę; brak wsparcia społecznego (również mentora) dającego wsparcie w realizacji nowych ról; wyręczające w obowiązkach otoczenie (np. rodzice, instytucje państwowe i społeczne, inni bliscy); brak wypracowania własnego sposobu realizacji ról; dążenie do sztywnego i niedostosowanego do możliwości i kontekstu realizowania ról pracownika i partnera (Bee, 2003, za: Harwas-Napierała, 2014). Swoistym uzupełnieniem powyższego jest zestawienie generalnych zagrożeń występujących na różnych etapach dorosłości klasyfikowanych przez Barbarę Harwas-Napierałę jako: utrudnione budowanie intymnych relacji, komercjalizacja roli rodzicielskiej, brak wartościowych wzorów identyfikacyjnych, frustracja generatywności, egocentryzacja i infantylizacja dorosłych oraz trudnienia w osiąganiu profesjonalizacji zawodowej (2014). Odroczenie 
w czasie ważnych decyzji życiowych przez młodych dorosłych oraz podejmowanie kształcenia na wyższych szczeblach nauczania traktowane są zatem jako przejawy transformacji dokonujących się w społeczeństwach kultury zachodniej w ostatnich dekadach.

Wobec wskazanych powyżej licznych zagrożeń towarzyszących wchodzeniu w kolejne fazy rozwojowe, w próbie uchwycenia całościowego horyzontu uwarunkowań towarzyszących wczesnej dorosłości, na uwagę zasługuje, stanowiąca niejako egzemplifikację wcześniej wymienionych i skatalogowanych, kategoria sensu życia. Dylematy egzystencjalne powstające na bazie trudności pełnienia ról społecznych, konstruowania tożsamości i wyznaczania celów, wiążące się z dużą liczbą różnych typów konfliktów ujawnianych na dorosłej drodze życia (Brzezińska, 2002, s. 13) są bowiem ściśle związane z kluczową dla egzystencji potrzebą o charakterze meta - potrzebą sensu życia. Niemożność zaspokojenia potrzeby sensu życia skutkuje doświadczeniem bezsensu, pustki, rozpaczy i alienacji, współtworzących zespół objawów w klinicznym obrazie depresji, zaś w ujęciu koncepcji sensu życia Victora Frankla prowadzi do triady egzystencjalnej obejmującej: agresję, depresję i nałogi (Frankl, 1998). Wobec różnych obszarów psychospołecznej aktywności młodych dorosłych, takich jak tworzenie niszy społecznej, budowanie rodziny i rozpoczynanie kariery zawodowej (Brzezińska, 2002) wyróżnione desygnaty braku sensu życia stają się poważną barierą na drodze budowania spójnego i harmonijnego konstruktu dorosłości. W skrajnych przypadkach, zwłaszcza w zestawieniu z towarzyszącą przeżywaniu sytuacji problemowych depresją, mogą one w konsekwencji braku profesjonalnej psychoterapeutycznej pomocy i wsparcia znaczących innych prowadzić do kryzysu suicydalnego oraz zachowań suicydalnych zakończonych zgonem.

Konkludując, warto przypomnieć, że wybrane aspekty funkcjonowania młodych dorosłych z perspektywy ujęć teoretycznych proponowanych np. w psychologii społecznej obejmujące m.in. komunikację międzypokoleniową oraz reguły i normy społeczne (Rosiński, 2013) stanowią zarazem silny potencjał ochronny w zakresie ryzyka zachowań suicydalnych jak i potencjalne źródło wartości sensotwórczych w odniesieniu do analizowanej generacji.

\section{Zachowania suicydalne - próba uchwycenia specyfiki zjawiska}

Zachowania suicydalne na przestrzeni dziejów, odbijające się trwałym piętnem śmierci, przez filozofów opisywane jako graniczne sytuacje egzystencjalne, nieodmiennie wpisują się w kondycję egzystencjalną człowieka oraz historię ludzkości. W heterogenicznych poglądach na temat samobójstwa w świecie starożytnym zamachy samobójcze jako zjawisko dość często spotykane, generując zarazem zachętę wyrażaną przez stoików, jak i potępienie przez czołowych myślicieli, tj. Platona (czyn haniebny) i Arystotelesa (tchórzostwo), ostatecznie zyskują pragmatyczne konsekwencje prawne. Krytyczne podejście do samobójstw 
charakterystyczne dla średniowiecza, wynikające z założeń chrześcijaństwa, dla którego życie ludzkie stanowi rodzaj daru i przedmiot odpowiedzialności, znajdując kontynuację w okresie renesansu, w ramach myśli oświeceniowej traci na znaczeniu i samobójstwo staje się wyrazem wolności, podczas gdy w romantyzmie jest odpowiedzią na udręki duszy i opresję społeczną, zaś w nowożytności staje pod znakiem zapytania wraz z pojawieniem się naukowej psychiatrii i socjologii, stanowiąc wynik opresji i alienacji społecznej oraz skutek uboczny nowoczesności (Adamczyk, 2014, s. 12-19).

Samobójstwo uważa się obecnie za zjawisko wielowymiarowe, będące wynikiem złożonej interakcji czynników biologicznych, genetycznych, psychologicznych, socjologicznych i środowiskowych i choć jest także problemem zdrowotnym, to w znacznym zakresie jest problemem społecznym, psychologicznym i szerzej socjoekonomicznym. Wokół pojęcia samobójstwa definiowanego z punktu widzenia różnych dyscyplin naukowych (filozofii, psychologii, socjologii, etyki, kryminologii, prawa, suicydologii etc.) istnieją zróżnicowane kryteria oceny i definicji, stąd trudno o jednoznaczny opis i definiowanie zjawiska o tak wysokim stopniu złożoności i przenikających konotacjach indywidualnych i środowiskowych.

Filozoficzny namysł nad problemem samobójstwa pozwala na ujmowanie go w kontekście antycznego modelu samodoskonalenia, chrześcijańskiej idei zbawienia, moralnej zasady użyteczności, samowiedzy i czynu, samoafirmacji mocy, wolności egzystencjalnej, autodekonstrukcji i autodestrukcji, dobrowolnej eutanazji i granic ludzkiej autonomii (Kijaczko 2005, s. 5). Jednak ze względu na swój polemiczny charakter wszelkie jego uzasadnienia nie są ostateczne. Moralny sens samobójstwa przynosi konstatację, zgodnie z którą na żadnym szczeblu kulturowego rozwoju ludzkości położenie kresu własnemu życiu nie jest pozostawione decyzji jednostki nienormowanej określonym obyczajem społecznym, zawsze bowiem podlega ono odpowiednim kategoriom moralnym, zakazom czy nakazom co sprawia, że stanowią one integralny element moralnej tradycji ludzkości (Ślipko, 2008, s. 54).

Na gruncie psychologii autodestruktywności pojawia się cały szereg problemów dotyczących definiowania i kwalifikowania zachowań i struktur psychicznych jako autodestrukcyjnych. Różne teorie osobowości i związane z nimi modele psychicznej autodestruktywności rozpatrują samobójstwo jako wynik ścierania się w ludzkim życiu psychicznym dwóch sprowadzalnych do mechanizmów biologiczno-popędowych tendencji: negentropijnej i entropijnej (Zygmunt Freud) czy też jako patologiczny sposób samorealizacji (Erich Fromm); jako swoisty przejaw tendencji obronnych psychiki ludzkiej (Abraham H. Maslow) bądź jako wyraz właściwego każdemu człowiekowi dążenia do mocy (Alfred Adler); jako nieadekwatny sposób rozwiązywania przez jednostki problemów, rezultat niezaspokojenia bądź wypaczenia potrzeb psychologicznych osoby (Edwin Shneidman) czy wreszcie jako efekt kumulacji silnych napięć emocjonalnych mogących prowadzić do działań samobójczych (Kijaczko, 2005, s. 9). Analizując zachowania suicydalne 
w warstwie socjologicznej podbudowy teoretycznej, nieodłącznie pojawia się odwołanie do klasycznej teorii samobójstwa Emile'a Durkheima (2011) ugruntowanej w świecie nauk społecznych i humanistycznych, a klasyfikującej cztery podstawowe typy samobójstwa: egoistyczne, altruistyczne, anomiczne i fatalistyczne (Nieporowski, 2014, s. 57).

Według założeń suicydologii, dziedziny interdyscyplinarnej w wymiarze teoretycznym, metodologicznym i praktycznym, a zarazem nauki zajmującej się badaniem zachowań samobójczych, ich uwarunkowań i metod zapobiegania, aktywność autodestrukcyjna, której wyrazem jest samobójstwo jako skrajna postać negacji życia, analizowana jest zarówno na gruncie niehomogenicznej natury jak i czynników sprawczych w skumulowanej postaci, tworzących sytuacje ekstremalnie trudne. Typologie sytuacji suicydogennych klasyfikowane są przez suicydologów, uwzględniając zarówno czynniki egzogenne, tkwiące w małych grupach społecznych, w makroskali np. w sytuacji anomii i dezorganizacji społecznej, a więc występujących w postaci czynników o charakterze psychospołecznym, jak czynniki pochodzenia endogennego, wewnątrzorganicznego (Bielicki, 2004, s. 45-46).

W ramach wieloośrodkowych badań WHO/EURO - SUPRE-MISS (Światowa Inicjatywa dla Zapobiegania Samobójstwom) zdefiniowano zespół podstawowych pojęć związanych z samobójstwem obejmujących: myśli samobójcze - fantazje, wyobrażenia i przemyślenia na temat samobójstwa, a także życzenia i impulsy do jego podjęcia; próby samobójcze (attempt suicide, deliberate selfhaim, parasuicide) - działania podjęte bez tragicznego zakończenia życia, w których jednostka rozważa: zapoczątkowanie nietypowego zachowania bez udziału osób drugich, mogącego doprowadzić do samouszkodzenia albo przyjęcie substancji $\mathrm{w}$ dawce większej niż terapeutyczna (ewentualnie terapeutycznej) w celu osiągnięcia zmiany poprzez aktualne lub oczekiwane fizyczne konsekwencje (Międzynarodowa, 2006); proces samobójczy - narastanie zagrożenia popełnienia samobójstwa od poważnych myśli samobójczych do podjęcia próby samobójczej (jednej lub wielokrotnej), ewentualnie dokonanego samobójstwa mającego swoją dynamikę obejmującą: początek, różne fazy rozwoju, określony czas trwania); zachowania samobójcze - myśli samobójcze, próba samobójcza, samobójstwo dokonane; samobójstwo dokonane - przemyślane, zamierzone działanie zagrażające życiu jednostki, podjęte samodzielnie, którego następstwem jest śmierć (Rosa i Gmitrowicz 2007, s. 20).

Pamiętając, że samobójstwo jest zjawiskiem wielowymiarowym, będącym wynikiem interakcji pomiędzy wieloma czynnikami szacuje się, że u ok. 80\% osób dokonujących skutecznego samobójstwa występowały zaburzenia psychiczne (Jaeschke, Siwek, Dudek, 2011, s. 574). Do czynników indywidualnych i socjodemograficznych mających związek z samobójstwem należą: zaburzenia psychiczne (najczęściej depresja, alkoholizm, schizofrenia i zaburzenia osobowości); choroba somatyczna (terminalna, bolesna, inwalidyzująca, aids); wcześniejsze próby samobójcze; przypadki samobójstwa, alkoholizmu i/lub innych zaburzeń psychicznych 
w rodzinie; stan cywilny: wdowieństwo, rozwód, stan wolny; osamotnienie (życie w izolacji społecznej); brak pracy lub przejście na emeryturę; utrata bliskich (osierocenie) w dzieciństwie (Zapobieganie, 2003, s. 16). Szacuje się, że ryzyko popełnienia samobójstwa w ciągu życia przez osoby z zaburzeniami nastroju (czyli głównie depresją) wynosi $6-15 \%$, z alkoholizmem $7-15 \%$, a ze schizofrenią 4-10\% (Jaeschke, Siwek, Dudek, 2011, s. 574).

Katalog uznanych narzędzi psychometrycznych stosowanych do oceny ryzyka samobójstwa tworzą: Wystandaryzowana skala SAD PERSONS, Skala NO HOPE, Skala beznadziejności Becka, Skala oceny myśli samobójczych Becka. Skale depresji dostępne w Polsce, w których występuje odrębny punkt szacujący nasilenie występowania zachowań samobójczych, obejmuje: Inwentarz Depresji Becka, Skalę Depresji Hamiltona, Wywiad w kierunku zaburzeń depresyjnych według ICD-10 (Uznane, 2015, s. 239-241).

Aktualne dane policyjne konkretyzujące zjawisko samobójstw w Polsce, ze szczególnym uwzględnieniem generacji młodych dorosłych, w postaci zestawionych danych szczegółowych wykazują, że zamachy samobójcze dokonane zakończone zgonem w roku 2017 objęły: 5276 osób (4524 mężczyzn, 751 kobiet), w tym 1258 osób w okresie wczesnej dorosłości. W roku 2018 zamachy samobójcze dokonane zakończone zgonem: 5182 (4471 mężczyzn, 711 kobiet), w tym w okresie wczesnej dorosłości: 1171 osób. Zamachy samobójcze usiłowane (próby samobójcze) w roku 2017: 11139 osób (8515 mężczyzn, 2623 kobiet), w tym 3605 młodych dorosłych, zaś w roku 2018: 11167 osób (8364 mężczyzn, 2803 kobiet), w tym 3473 młodych dorosłych (Satystyka.policja.pl).

Warto zwrócić uwagę, że aktywność autodestrukcyjna ludzi w normie intelektualnej, emocjonalnej i wolicjonalnej stanowi rezultat długo funkcjonujących i wywierających presję czynników sytuacyjnych, doprowadzając do skrajnego zmęczenia życiem naznaczonym poczuciem głębokiej beznadziejności i bezsensu dalszego trwania, a sygnalizowane tendencje samobójcze są wołaniem o pomoc innych ludzi, których aktywność łagodząca traumatyzujący charakter sytuacji może zapobiec dokonaniu samobójstwa (Bielicki, 2004, s. 46). Kluczowym wydaje się zatem odwołanie po raz kolejny do metapotrzeby, jaką stanowi potrzeba sensu życia, której niemożność zaspokojenia prowadzi do stanów depresyjnych, nerwicy noogennej, doświadczenia pustki, rozpaczy i wyobcowania, a w konsekwencji zwiększa ryzyko podjęcia zamachu samobójczego.

\section{Profilaktyka egzystencjalna - ku wartościom sensotwórczym}

Zakładając, że życie osobnicze jednostki potencjalnie narażonej na działania autodestrukcyjne stanowi podstawowy problem w organizacji profilaktyki samobójstw, wszelkie działania profilaktyczne zarówno o charakterze systemowym (psychoprofilaktyka, poradnictwo, edukacja zdrowotna, edukacyjne programy profilaktyczne), podejmowane w obrębie zorganizowanych inicjatyw oddolnych 
w ramach organizacji środowiska życia (organizacje pozarządowe (Koszewska, 2016), Projekt Rappedagogia), jak i aktywizowane samodzielnie w próbach wyjścia z traumatycznej sytuacji (rodzina, lekarz pierwszego kontaktu, poradnia zdrowia psychicznego, grupa wsparcia, pomoc duchowa etc.), powinny stanowić element życia osobniczego, w którym będzie możliwa pozytywna projekcja w przyszłość w zakresie celów, planów, wartości sensotwórczych. W kontekście wartości sensotwórczych, lokując potrzebę działań profilaktycznych w programach obejmujących profilaktykę pierwszego, drugiego i trzeciego stopnia należałoby ująć treści obejmujące zagadnienia: a) poszukiwania sensu życia, wzmacniania pozytywnych cech charakteru i pozytywnych postaw wobec życia; b) kształtowania postaw życzliwego i aktywnego zaangażowania w sprawy ludzkie; c) wsparcia w samodzielnym rozwiązywaniu problemów; d) kształtowania postaw uważności na zachowania rezygnacyjne; e) upowszechniania wiedzy o kryzysie suicydalnym; f) kształtowania umiejętności radzenia sobie w sytuacjach trudnych (Moczuk, Jedynak, 2018, s. 179-180).

Profilaktyka samobójstw umieszczona w koncepcjach poradnictwa życiowego, jak twierdzi Bielicki, winna przede wszystkim stwarzać warunki do zaspokojenia potrzeby sensu życia i wzmocnienia potencjału wartości życia jednostki funkcjonującej w ekstremalnie trudnej sytuacji życiowej i drastycznej opresji, w której rodzą się myśli samobójcze, potwierdzające lub negujące istnienie (Bielicki, 2004, s. 45). W obrębie propozycji profilaktycznej Bielickiego zarysowany obszar zadań profilaktycznych obejmuje:

1) strategię informacyjno-edukacyjną skierowaną do szerszych kręgów społecznych opartą na wiedzy i badaniach naukowych dotyczących: a) etiologii zamachów samobójczych, b) symptomów kształtowania się trendu samobójczego (zaniżona samoocena, niska odporność na czynniki stresogenne, brak umiejętności rozwiązywania sytuacji trudnej, w tym sytuacji deprywacji, poczucie braku oparcia w otoczeniu, szczególnie w rodzinie, zmienność nastrojów, czasem zachowania agresywne, objawy depresyjne, alienacja); c) roli czynników sytuacyjnych (trudna sytuacja rodzinna z czynnikami dezorganizacji i demoralizacji); d) symptomów zaburzeń psychicznych; e) informowania o preferencyjnych celach życiowych i wartościach w celu kształtowania osobowości kreatywnych;

2) profilaktykę specjalno-zapobiegawczą prowadzoną za pomocą metod oddziaływania: a) bezpośrednich (dla osób manifestujących objawy zachowań suicydalnych oparte na wpływie osobistym) i b) pośrednich (stawianie wzorów do naśladowania w sytuacjach zagrożenia, ukazywanie sensu życia mimo traumatycznej sytuacji);

3) taktykę działań profilaktycznych wraz z diagnozami cząstkowymi odnoszącymi się do symptomów sytuacyjnych, wykrywanych w całym lub zbliżonym syndromie sytuacji suicydogennej, uwzględniając: a) diagnozę pozwalającą na wykrywanie osób zagrożonych samobójstwem, b) diagnozę sytuacji zewnętrznej, 
środowiskowej, interakcyjnej z osobami z tej samej grupy społecznej, c) diagnozę psychofizyczną (Bielicki, 2004, s. 50-56). Wysoki procent osób popełniających samobójstwo, umiera nie kontaktując się wcześniej z poradnią zdrowia psychicznego, stąd zwiększenie wykrywalności zaburzeń psychicznych, częstsze kierowanie takich osób do specjalisty i leczenie zaburzeń psychicznych w podstawowej opiece zdrowotnej jest ważnym krokiem w zapobieganiu samobójstwom (Zapobieganie, 2003, s. 9).

Doświadczenia niektórych krajów (Szwecja, Finlandia, Norwegia, Dania, Wielka Brytania) dowodzą, że wczesne wykrywanie, efektywne leczenie i zapobieganie chorobowym zaburzeniom nastroju może przyczynić się nie tylko do zwiększenia długości życia chorych, ale również do zmniejszenia współczynników samobójstw w populacji ogólnej. Cel ten w wielu krajach realizowany jest w formie krajowych programów zapobiegania samobójstwom. (Brodniak, 2012, s. 4). Edukacja lekarzy nad rozpoznawaniem i leczeniem depresji oraz ograniczenia (restrykcje) w dostępie do śmiercionośnych metod odbierania sobie życia (broń, leki, trucizny itp.) są ważnymi metodami zapobiegania samobójstwom. W Finlandii, Szwecji, Estonii, Norwegii, na Węgrzech i kilku innych krajach wprowadzenie w latach dziewięćdziesiątych różnych programów i strategii zapobiegania samobójstw było jednym z czynników zmniejszenia w okresie 10-15 lat liczby i współczynników samobójstw w tych krajach o 30 do nawet prawie 50 procent, w czym znaczny udział miało uruchomienie w 1953 roku telefonu zaufania dla osób w kryzysie suicydalnym przez stowarzyszenie Samarytan w Wielkiej Brytanii (Brodniak, 2012, s. 17-22).

Ważnym elementem wspomnianych wcześniej wieloośrodkowych badań WHO/EURO - SUPRE-MISS dotyczących samobójstw jest szeroko pojęta prewencja samobójstw rozumiana jako zespół działań mogących zmniejszyć liczbę zachowań samobójczych, śmiertelność i konsekwencje (skutki) społeczne, zdrowotne i ekonomiczne związane z zachowaniami samobójczymi, obejmująca typy prewencji: indywidualną, rodzinną, szkolną, w miejscu pracy, w różnych organizacjach społecznych, w otoczeniu ofiary, dla terapeutów, a także poziomy interwencji: 1) w zakresie zdrowia publicznego - strategia adresowana do całego społeczeństwa, polegająca na promowaniu zdrowego stylu życia, pogłębianiu wiedzy na temat uwarunkowań samobójstw, możliwych źródeł pomocy, informowaniu w publikacjach książkowych, poradnikach), prasie i mediach elektronicznych (TV, internet, radio); 2) w zakresie opieki zdrowotnej - strategia pośrednia, uwzględniająca poprawę diagnostyki zaburzeń psychicznych, zwłaszcza depresyjnych, dostępności leczenia, niespecyficzna, redukująca sytuacje kryzysowe; 3) strategia specyficzna adresowana do jednostki z zachowaniami samobójczymi obejmująca usuwanie czynników mogących się bezpośrednio przyczyniać do zwiększonego zagrożenia jednostki samobójstwem przez pomoc psychospołeczną oraz kryzysowe interwencje psychologiczne i psychiatryczne (Rosa i Gmitrowicz 2007, s. 20). 
Polska propozycja programu zapobiegania samobójstwom w ramach programów ochrony zdrowia obejmuje wdrożenie zespołu działań edukacyjnych, pomocowych, terapeutycznych i interwencyjnych, uwzględniających szczegółowe cele obejmujące konkretne działania obejmujące: 1) uruchomienie wirtualnego informatora o telefonach zaufania, portalach pomocowych, o ośrodkach interwencji kryzysowej, poradniach zdrowia psychicznego, ośrodkach ostrych zatruć, poradniach psychologiczno-pedagogicznych i innych placówkach pomocy w całym kraju; 2) wprowadzenie ogólnopolskiego, całodobowo działającego telefonu zaufania i pomocowego portalu internetowego; 3) wprowadzenie systemu kształcenia podyplomowego lekarzy podstawowej opieki zdrowotnej w Polsce w zakresie rozpoznawania i leczenia zaburzeń afektywnych (depresyjnych), diagnozowania zagrożeń suicydalnych (myśli i plany samobójcze) i udzielania pomocy osobom w kryzysach suicydalnych i współpracy między różnymi placówkami specjalistycznymi i pomocowymi; 4) program szkoleń dla pedagogów szkolnych oraz pedagogów i psychologów z Poradni Psychologiczno-Pedagogicznych, pracowników pomocy społecznej, pracowników telefonów zaufania, a także duchownych i księży z parafii Kościoła rzymskokatolickiego i duchownych innych wyznań w zakresie rozpoznawania symptomów zachowań samobójczych (realizatorzy: psychiatrzy z doświadczeniami leczenia depresji, psycholodzy kliniczni zatrudnieni w placówkach psychiatrycznej opieki zdrowotnej i ośrodkach interwencji kryzysowej, pedagodzy i psycholodzy ze specjalnością interwencji kryzysowych i doświadczeniem pracy zawodowej z osobami w kryzysach suicydalnych i po próbach samobójczych; 5) zwiększenie dostępności do ośrodków interwencji kryzysowych przez zwiększenie ich liczby z rozszerzeniem zadań na osoby w kryzysie suicydalnym; wdrożenie do realizacji wojewódzkich programów zapobiegania samobójstwom w ramach programów ochrony zdrowia psychicznego (Brodniak, 2012, s. 17-20).

Istotnym obszarem działań prewencyjnych, jest kwestia wielopostaciowego wsparcia udzielanego rodzinie, którą Anthonny Giddens (2001) nazywa jądrem życia i tożsamości, a która w obliczu zmian wzorców postępowania między pokoleniami pozbawionymi naturalnych źródeł wsparcia ukrytych w rodzinnym doświadczeniu, może ulec destabilizacji zarówno pod wpływem negatywnych i traumatogennych czynników zewnętrznych, jak i w wyniku wydarzeń normatywnych, wiążących się z zaburzeniem homeostazy pomiędzy środowiskiem a jednostką (Farnicka, 2014, s. 129).

Potencjalnie ważne źródło wsparcia wpisujące się w profilaktykę egzystencjalną może stanowić zaangażowanie w życie wspólnotowe będące uobecnieniem przeżywania wiary i religii dla osób ceniących te wartości, w kontekście formacyjnym, zapewniającym potencjalne wsparcie i pomoc w przeżywanych trudnościach życiowych, traumatycznych doświadczeniach czy granicznych sytuacjach egzystencjalnych. Życie wspólnotowe jako najbardziej ludzka forma egzystencji (Vanier, 2011, s. 131) i zaangażowanego uczestnictwa w życiu innych umożliwia 
swoistą wymianę dóbr, doświadczenia korektywne oraz wzmacniające własny potencjał relacje osobowe pozwalające wyjść poza samotność i alienacje towarzyszące współcześnie człowiekowi. Wspólnota stanowiąca przestrzeń budowania głębokich więzi i relacji międzyludzkich stanowi również szansę neutralizowania i eliminowania negatywnych postaw zdeterminowanych siłą czynników traumatyzujących, w konsekwencji wzbudzających destruktywną orientację życiową.

Kwestię profilaktyki zagrożeń rozwoju można rozpatrywać także w szerszym kontekście wspomagania rozwoju człowieka rozumianego jako stwarzanie warunków do pomyślnego przebiegu tego procesu. Wspomaganie to obejmuje zarówno takie oddziaływania, które jednostka może sama stosować wobec siebie w ramach autokreacji rozwoju oraz stanowiące domenę jej środowiska społecznego, zwłaszcza rodzinnego. Realizacja tych działań jest możliwa w ramach dwóch (przenikających się w praktyce) nurtów: 1) edukacyjnego - popularyzowanie podstawowej wiedzy o rozwoju człowieka, pomoc w jej zdobywaniu, selekcji i korzystaniu z niej; 2) terapeutycznego - przejawiającego się w formie specjalistycznej i niespecjalistycznej obejmującej udzielanie podtrzymującego wsparcia przez osoby bliskie (małżonków, partnerów życiowych, przyjaciół) (Rostowska, 2008).

W odniesieniu do podjętego w niniejszym tekście wątku zachowań suicydalnych w okresie wczesnej dorosłości, ważnym zadaniem w zakresie szeroko pojętej profilaktyki zachowań suicydalnych na poziomie konstruowania programów profilaktycznych byłoby uwzględnienie dopełniających się obszarów problemowych, koncentrujących się wokół zagadnień uwarunkowań psychologicznych i społecznych aktywności dorosłych w edukacji oraz badań nad motywami i potrzebami uczestnictwa dorosłych w edukacji obejmujących: 1) psychologiczne możliwości i uwarunkowania kształcenia ludzi dorosłych; 2) społeczne uwarunkowania aktywności dorosłych w edukacji; 3) badania nad motywami i potrzebami uczestnictwa w edukacji dorosłych (Stopińska-Pająk, 2018, s. 18-20). Z uwagi na fakt, że działania w okresie wczesnej dorosłości wiążą się z dalszym uzyskiwaniem wykształcenia na poziomie akademickim, wyznaczaniem pierwszych doświadczeń zawodowych, stawianiem celów długofalowych, warto w kontekście profilaktyki egzystencjalnej, uwzględniającej aspekt edukacyjny, odwołać się również do profilaktycznej roli kształcenia akademickiego jako miejsca, w którym uczenie się jest wydarzeniem, namysłem nad rzeczywistością, powrotem do źródeł pedagogii - jej filozoficznego jądra i refleksji nad samym sobą, w opozycji do transmisyjnego charakteru oraz neoliberalnych uwikłań (Wajsprych, 2018, s. 43). Można wobec powyższego mówić o potrzebie swoistego przygotowania do dorosłości rozumianego jako długotrwały, podmiotowy, zindywidualizowany proces uczenia się dorosłości, silnie uwarunkowany społecznie i kulturowo przez szkołę, instytucje pracy, media masowe, instytucje wyznaniowe, a przede wszystkim rodzinę, którego celem jest jak najpełniejsze przygotowanie (się) młodego człowieka do pełnienia ról związanych z dorosłością, do świadomego i odpowiedzialnego wkroczenia w dorosłość 
oraz do doskonalenia siebie jako człowieka w trakcie realizacji dorosłego życia (Dubas, 2015, s. 23).

Swoiste podsumowanie łączące powyższe wskazania profilaktyczne w okresie wczesnej dorosłości, a zarazem ważne pole aktywności własnej w obrębie samowychowania, autoedukacji i edukacji permanentnej, wobec traumatogennych, a zarazem obciążających aspektów ludzkiego życia, stanowi koncepcja transgresji Józefa Kozieleckiego, w ramach której działania transgresyjne, czyli twórcze, innowacyjne, ekspansywne, a zarazem przekraczające dotychczasowe granice ludzkich osiągnięć materialnych, poznawczych i społecznych, zmieniając społeczeństwo i rozwijając kulturę ostatecznie kształtują osobowość (2004, s. 12), co z kolei stwarza silny i stabilny element profilaktyki egzystencjalnej redukujący rozmiary ryzyka egzystencjalnego na bazie potrzeb w: świecie materialnym, poznawczym, (symbolicznym), społecznym i świecie zewnętrznym (Kozielecki, 2004, s. 82-83).

\section{Podsumowanie - w odniesieniu do problemu czlowieka}

Problem kondycji egzystencjalnej człowieka można odnieść do podstawowego filozoficznego problemu, jakim jest problem człowieka i jego sytuacji w świecie, włączając w powyższy dylemat fundamentalne pytanie o człowieka: kim jest człowiek, jaka jest jego istota, co wyróżnia człowieka spośród świata rozmaitych istnień, jaki jest sens jego egzystencji, a co za tym idzie zagadnienie genezy ludzkiej istoty, tego czy jest ona $\mathrm{z}$ góry określona i dana, w jakim stopniu człowiek jest stwórcą samego siebie, a w jakim tworem przyrody, wytworem historii, kultury, czy szeroko rozumianej cywilizacji? (Piecuch, 2006, s. 7).

Spośród wszystkich problemów, z jakimi boryka się człowiek współczesny do ważnych zaliczyć można: określenie własnej tożsamości, problem zakorzenienia, zdefiniowanie celów życiowych będących zobowiązaniem na całe życie, a także dających poczucie sensu własnego istnienia stanowiącego czynnik ochronny przed kryzysem egzystencjalnym. Wskazując zarazem na dwa konteksty, w jakich kryzys ten się ujawnia: indywidualny i wspólnotowy, należałoby się odwołać do potencjału troski wzajemnej, wzajemnego współbycia i wspólnotowości jako niezmienników ludzkiego życia społecznego (Gałdowa, 2004, s. 250). Być może zatem do ważnych komponentów profilaktyki egzystencjalnej niejako z nią współistniejących należałoby włączyć kategorię wspólnoty jako opozycję dla postaw separacyjnych i izolacyjnych, trafnie wpisujących się we współczesny dogmat indywidualizmu zakorzenionego $\mathrm{w}$ prymat kultury masowej i gospodarki wolnorynkowej. Znamiennym jest, że społeczeństwa rozwijające się, gdzie na pytania, refleksje i dylematy egzystencjalne odpowiada się często z poziomu dóbr, usług i konsumpcji, notują szczególnie wysokie wskaźniki zamachów samobójczych, zachowań ryzykownych i działań autodestrukcyjnych. Ważnym postulatem wydaje się w tym kontekście odniesienie się do suicydalnego wpływu nowych mediów, ze 
szczególnym uwzględnieniem Internetu jako narzędzia doświadczenia zapośredniczonego jak i współczesnego nośnika bezpośredniej promocji zachowań suicydalnych (fora internetowe, zamknięte grupy, portale społecznościowe), a także gloryfikacji swoistej filozofii jako orientacji życiowej, akcentującej nihilistyczną wizję życia.

Szersze spojrzenie na profilaktykę egzystencjalną przynosi konstatację dotyczącą zadań i wyzwań stojących przed pedagogiką, uprawomocnioną do zajęcia stanowiska wobec zagrożenia zachowaniami suicydalnymi, nie tylko z tytułu interdyscyplinarnej proweniencji, ale przede wszystkim z etosu przynależnego pedagogice, w ramach którego życie ludzkie jest najwyższą wartością. W ramach tak rozumianej pedagogiki można mówić o jej powinnościach skupionych m.in. wokół uwzględnienia w jej polu analiz teoretycznych i dociekań badawczych kategorii egzystencjalnych, w tym kategorii sensu życia ludzkiego (Śledzianowski, 2017, s. 165), kondycji egzystencjalnej, zagrożeń egzystencjalnych, pytań egzystencjalnych oraz zachowań autodestrukcyjnych. Pedagogiczne zanegowanie pytań egzystencjalnych i refleksyjnej natury człowieka na rzecz prymatu rozumu instrumentalnego obejmującego: konsumpcjonizm, instrumentalizację, uprzedmiotowienie własnego życia i innych ludzi, utratę zdolności do rozmowy i więzi z innymi, degradację języka, komercjalizację wszelkich działań, sprowadzenie dobra do korzyści, a zła do straty - prowadząc do dehumanizacji, jak twierdzi Robert Kwaśnica, wiedzie zarazem do utraty zdolności do swoiście ludzkiego sposobu bycia nazwanego egzystencją (2014, s. 89). Profilaktyka egzystencjalna to zatem obok niezbędnej realizacji programów i projektów profilaktycznych, kampanii społecznych i inicjatyw oddolnych, szeroko pojęte przeciwdziałanie wyniszczającym i degradującym ludzkie życie zjawiskom kryzysowym, takim jak: pustka, niedobór sensu i motywacji, poczucie winy, niezdolność obdarzania innych zaufaniem i empatyczną relacją z nimi, stające się normą za pomocą racjonalizowania dehumanizacji (Kwaśnica, 2014, s. 89).

\section{Bibliografia}

1. Adamczyk, K. (2014). Samobójstwo na przestrzeni wieków. W: M. Farnicka, E. Magda (red.), Samobójstwo. Jeden problem, trzy spojrzenia (s. 11-23). Zielona Góra: Oficyna Wydawnicza Uniwersytetu Zielonogórskiego.

2. Bee, H. (2003). Rozwój człowieka na przestrzeni życia. Poznań: Wydawnictwo Zysk i S-ka.

3. Brodniak, A. (2012). Ramowy Program zapobiegania samobójstwom w Polsce na lata 2012-2015 w ramach realizacji narodowego programu ochrony zdrowia psychicznego. Warszawa: Instytut Psychiatrii i Neurologii. Załącznik nr 4.

4. Brzezińska, A. (2002). Dorosłość - szanse i zagrożenia dla rozwoju. W: A. Brzezińska, K. Appelt, J. Wojciechowska (red.), Szanse i zagrożenia rozwoju w okresie dorostości. (s. 11-22). Poznań: Wydawnictwo Fundacji Humaniora. 
5. Brzezińska, A. Piotrowski, I.K. (2009). Diagnoza statusów tożsamości w okresie adolescencji, wyłaniającej się dorosłości i wczesnej dorosłości za pomocą Skali Wymiarów Rozwoju Tożsamości (DIDS). Studia Psychologiczne, nr 47 (3), s. 93-109.

6. Dubas, E. (2015). Przygotowanie do dorosłości. Być i stawać się dorosłym. Edukacja Dorostych, s. 9-23.

7. Frankl, V. (1998). Homo patiens. Warszawa: Instytut Wydawniczy Pax.

8. Gałdowa, A. (2004). Wspólnota i separacja. Aktualność myśli Alfreda Adlera. W: C. Piecuch (red.), Kondycja człowieka współczesnego (s. 249-255). Kraków: Towarzystwo Autorów i Wydawców Prac Naukowych UNIVERSITAS.

9. Harwas-Napierała, B. (2014). Niektóre współczesne zagrożenia rozwoju w okresie dorosłości. Psychologia rozwojowa. T. 19, $\mathrm{nr}$ 2, s. 23-32.

10. Hołyst, B. (2012). Suicydologia. Warszawa: LexisNexis.

11. Jaeschke, R., Siwek, M., Dudek, D. (2011). Neurobiologia zachowań samobójczych. Psychiatria Polska, tom XLV, nr 4, s. 573-588.

12. Kępiński, A. (1989). Lęk. W: J. Tischner (red.), Filozofia współczesna (s. 487-496). Kraków: Instytut Teologiczny Księży Misjonarzy.

13. Koszewska, I. (2016). Profilaktyka depresji i samobójstw w Polsce w latach 2009-2016 z perspektywy trzeciego sektora (organizacji pozarządowej). Suicydologia, t. VIII, s. 21-27.

14. Kozielecki, J. (2004). Społeczeństwo transgresyjne. Szansa i ryzyko. Warszawa: Wydawnictwo Akademickie ,Żak”.

15. Kwaśnica, R. (2014). Dyskurs edukacyjny po inwazji rozumu instrumentalnego. O potrzebie refleksyjności. Wrocław: Dolnośląska Szkoła Wyższa.

16. Malina, A. (2014). Wczesna dorosłość w cyklu życia człowieka. Współczesne problemy z realizacja zadań rozwojowych młodych dorostych. Bydgoszcz: Wydawnictwo Uniwersytetu Kazimierza Wielkiego.

17. Międzynarodowa Statystyczna Klasyfikacja Chorób i Problemów Zdrowotnych (ICD-10) (2006). T. 1. Kraków: Uniwersyteckie Wydawnictwo Medyczne VESALIUS.

18. Młodożeniec, A. (2015). Zapobieganie zamachom samobójczym młodzieży. W: A. Gmitrowicz, M. Makara-Studzińska, A. Młodożeniec (red.), Ryzyko samobójstwa u młodzieży. Diagnoza, terapia i profilaktyka (s. 213-229). Warszawa: Wydawnictwo Lekarskie PZWL.

19. Piecuch, C. (2004). Kondycja człowieka współczesnego. Kraków: Towarzystwo Autorów i Wydawców Prac Naukowych UNIVERSITAS.

20. Projekt Rappedagogia, Pobrane z: http://makowskidobromir.pl/rappedagogia.html (29.06.2019).

21. Rosa, K. Gmitrowicz A. (2007). Regionalny Program Zapobiegania Samobójstwom Młodzieży. Charakterystyka populacji regionu kłodzkiego. Suicydologia, t. 3, nr 1.

22. Rosiński, D. (2013). Wczesna dorosłość - wybrane aspekty z perspektywy psychologii społecznej. Polityka Społeczna, nr 40, t. 2, s. 8-14.

23. Rostowska, T. (2008), Malżeństwo, rodzina, praca a jakość życia. Kraków: Oficyna Wydawnicza „Impuls”.

24. Statystyka.policja.pl. Pobrane z: http://statystyka.policja.pl/st/wybrane-statystyki/ zamachy-samobojcze/63803, Zamachy-samobojcze-od-2017-roku.html (dostęp: 29.06.2019). 
25. Stopińska-Pająk, A. (2018). Tożsamościowy plecak - meandry rozwoju andragogiki w Polsce - narracja historyczna w perspektywie minionego stulecia. Edukacja Dorostych, $n$ r 2, s. 13-25.

26. Suchodolski, B. (1999). Skad i dokąd idziemy. Warszawa: Warszawskie Wydawnictwo Literackie Muza SA.

27. Śledzianowski, J. (2017). Samobójstwo w dziejach i cywilizacji śmierci. Kielce: Wydawnictwo JEDNOŚĆ.

28. Uznane narzędzia psychometryczne do oceny ryzyka samobójstwa (2015). W: A. Gmitrowicz, M. Makara-Studzińska, A. Młodożeniec (red.), Ryzyko samobójstwa u młodzieży. Diagnoza, terapia i profilaktyka (s. 239-244). Aneks 1. Warszawa: Wydawnictwo Lekarskie PZWL.

29. Wajsprych, D. (2018). Z czego nie można zrezygnować podczas uczenia się w dorosłości? O myśleniu, działaniu i uważności. Edukacja Dorostych, $n r$ 2, s. 43-58.

30. Zapobieganie samobójstwom. Poradnik dla lekarzy pierwszego kontaktu (2003). Genewa - Warszawa: Światowa Organizacja Zdrowia, Polskie Towarzystwo Suicydologiczne.

\section{PREVENTION OF EXISTENTIAL PROBLEMS LEADING TO SUICIDAL BEHAVIOURS IN THE EARLY ADULTHOOD}

Keywords: prevention of existential problems, suicidal behaviours, young adults, adult education, meaning of life.

Abstract: For many years, the phenomenon of suicidal behaviours among young adults has been observed not only in Poland. The paper describes selected areas of contemporary threats to the existential condition and the role of broadly meant prevention, emphasising the need for prevention of existential problems leading to suicidal behaviours in the early adulthood.

Dane do korespondencji:

\section{dr Jolanta Spętana prof. WWSSE}

Wielkopolska Wyższa Szkoła Społeczno-Ekonomiczna w Środzie Wlkp.

ul. Surzyńskich 2

63-000 Środa Wielkopolska 